\title{
Phytotoxic Effect of Pre emergence Herbicides on Oil Content and Yield Components of Groundnut (Arachis hypogeae)
}

\author{
Soumya Kumar Sahoo ${ }^{1 *}$, Jyostnarani Pradhan², V.B. Kuruwanshi ${ }^{1}$, \\ Arti Guhey ${ }^{1}$, G.R. Rout ${ }^{3}$ and Rabiratna Dash $^{3}$ \\ ${ }^{1}$ Department of Plant Physiology, Indira Gandhi Krishi Vishwavidyalaya, \\ Raipur, C.G, 492012, India \\ ${ }^{2}$ Department of Plant Physiology, Banaras Hindu University, Varanasi, U. P, 221005, India \\ ${ }^{3}$ Department of Plant Physiology \& AICRP on Weed Management, Orissa University of \\ Agriculture and Technology, Bhubaneswar, Odisha-751003, India \\ *Corresponding author
}

\begin{tabular}{|c|c|}
\hline & B S T R A C T \\
\hline & \multirow{5}{*}{$\begin{array}{l}\text { We studied the phytotoxic effect of three pre-emergence herbicidal treatments such as } \\
\text { butachlor, alachlor, oxyflurofen along with weedy check control and weed free check } \\
\text { (hand weeded) treatments having three replication under Randomize Block Design (RBD) } \\
\text { to evaluate yield and yield attributes characters and oil content in groundnut (Arachis } \\
\text { hypogaea L.). It is fact that application of herbicides can check the weeds timely and } \\
\text { effectively but also believed that application of herbicides can alternate the ecology of } \\
\text { leguminous crop. This alternation in ecology may directly impair on yield and yield } \\
\text { attributes characters and oil content of groundnut. Based on our study it was found that all } \\
\text { the herbicidal treatments as well as weed free check significantly increased the yield and } \\
\text { yield attributing characters and oil content of groundnut as compared to weedy check } \\
\text { control. Among the all treatments, weed free treatment showed best results and recorded } \\
\text { highest yield (13.92 q/ha) followed by butachlor (13.17 q/ha) which increased to a tune of } \\
26.54 \% \text { and } 19.72 \% \text { respectively over weedy check control. Besides this harvesting oil and } \\
\text { oil percentage content was noted highest in weed free check ( } 6.86 \text { ha hand } 49.33 \% \text { ) } \\
\text { followed by butachlor (6.16 q/ha and } 46.78 \% \text { ). Retrieval the fact, it is resolved that beside } \\
\text { weed free treatment, application of pre emergence herbicides with two hand weeding at } 21 \\
\text { DAS and } 40 \text { DAS can increases the yield and oil content of groundnut crop significantly } \\
\text { over the weedy check control. }\end{array}$} \\
\hline Keywords & \\
\hline Article Info & \\
\hline $\begin{array}{l}\text { Accepted: } \\
21 \text { July } 2017 \\
\text { Available Online: } \\
10 \text { September } 2017\end{array}$ & \\
\hline & \\
\hline
\end{tabular}

\section{Introduction}

Groundnut (Arachis hypogaea L.) is an annual unpredictable legume cum oilseed crop which is belongs to family Fabaceae. It is the 13th principal economic food crop (Kabir et al., 2013) and 4th most important oilseed crop of the world (Taphee et al., 2014). Nearly $66 \%$ of the groundnut produced in the world is crushed for oil.
Groundnut seeds (kernels) contain 40-50\% oil, 20-50 \% protein and 10-20\% carbohydrate (Saveage and Keenan, 1994), besides this groundnut seeds are rich in fat soluble vitamins are $\mathrm{A}, \mathrm{D}, \mathrm{E}$ and $\mathrm{K}$ and water soluble vitamins B-Complex and vitamin C. Important essential minerals such as calcium, phosphorus, magnesium, zinc, iron, potassium, copper and 
selenium are also present in it (Settaluri et al., 2012).

Groundnut kernels are consumed directly as raw, roasted or boiled kernels or oil extracted from the kernel is used as culinary oil. It is also used as animal feed (oil pressings, seeds, green material and straw) and industrial raw material (oil cakes and fertilizer).Groundnut oil is well known for high quality edible oil but in the USA it is being targeted to produce groundnut biodiesel to run farm machinery to reduce the cost of farm operations (USDAARS, 2008; Wright, 2012). The residual oilcake is an important protein supplement in cattle and poultry feed. The cake can be used to manufacture artificial fiber. The haulms (plant stalks) are fed (green, dried or silaged) to livestock or in manuring. Groundnut shells are used to manufacture coarse boards, cork substitutes etc. These multiple uses of groundnut plant make it an excellent cash crop.

Weeds are the major constraint which limits the production in groundnut, because it is highly susceptible to weed infestation due to its slow growth rate in the initial stages upto 45DAS which causes shortening of plant height and underground pod bearing habit. Unlike other crops, weed interfere with pegging, pod development and harvesting of groundnut during different stages of crop growth besides competing for essential resources. Therefore, weeds reduce crop yields by competing with crops mainly for light, nutrients, water, and carbon dioxide (Anderson 1989). The yield reduction due to weeds has been reported upto $30-80 \%$ (Gills et al., 2010). It is recorded that serious loss (25-40\%) in pods yield of groundnut is due to weeds infestations especially during the early stages of crop development (Jhala et al., 2005).

In the area of weed management during the last four decades, significant developments have been taken place in chemical weed control by using herbicide. Jaiswal (1994) noticed that, weed control efficiency of different herbicides treatment ranged from 40 to $91 \%$ was recorded in metribuzin $(91 \%)$ treatment. The effectiveness of a herbicide is governed by many factors like method of application; dose of herbicide and spray volume; weed species; soil conditions (type, moisture, organic matter, clay content and $\mathrm{pH}$ ); physiological stage of the crop and weeds and atmospheric temperature and humidity. Herbicide gives timely and effective control of weeds and traditional methods give better aeration and soil condition along with weed control. Therefore use of herbicide alone or in combination with cultural practices has become a necessity to control weeds.

The existing report showed that chemo toxic effects of various herbicides when applied indiscriminately had variable effects on legume production by alternating their ecology (Khan et al., 2004). The magnitude of the toxic effects of herbicides, however, depends primarily on the type and dose of compounds, duration of exposure, species and age of plants, and other environmental factors. When applied frequently, the herbicides are accumulated in to the soil and at elevated levels impair the metabolic activities resulting in reduced growth of rhizobia, legumes or both. For instance, the photosynthesis inhibiting herbicide (metribuzin) affects the Rhizobium sp. (Heinonen-Tanski et al., 1982), the plant (Rennie and Dubetz, 1984) and the legume Rhizobium symbiosis (Malik and Tesfai, 1985).

\section{Materials and Methods}

The field trials reported here was carried out in 2014-15 at Central farm, Orissa University of Agriculture and Technology, Bhubaneswar which is situated $85^{\circ} 52^{\prime} \mathrm{E}$ longitude and $20^{\circ}$ $15^{\prime} \mathrm{N}$ latitude with an elevation of 25.5 meters 
above sea level. The soil of the experimental field was sandy-loam having bulk density $1.56 \mathrm{gcm}^{4}$, Particle density $2.67 \mathrm{~g} . \mathrm{cm}^{-3}$, with low organic carbon $(0.38 \%)$ and it was moderately acidic $\mathrm{pH}$ (5.4).

\section{Details of the variety and treatments}

Variety of groundnut Devi was used for the study with three pre emergence herbicidal treatments. Devi is erect with moderate size pod containing 2-3 seeds. It matures between 110-115 days after sowing. The five treatments were such as

$\mathrm{T}_{0^{-}}$Weed check (Control),

$\mathrm{T}_{1}$-Butachlor 50\% EC) @ 1000ml/ha, with two hand weeding at $21 \& 40$ DAS

$\mathrm{T}_{2^{-}}$Alachlor (50\% EC) @ $800 \mathrm{ml} / \mathrm{ha}$, with two hand weeding at $21 \& 40$ DAS

$\mathrm{T}_{3^{-}}$Oxyflurofen (23.5\%EC) @ $80 \mathrm{ml} / \mathrm{ha}$, with two hand weeding at $21 \& 40$ DAS

$\mathrm{T}_{4}$ - Weed free check (Manual weeding)

\section{Application of manures and fertilizer}

One cart load of FYM was applied to the soil uniformly before $3^{\text {rd }}$ ploughing. Basal dose of $\mathrm{N}: \mathrm{P}: \mathrm{K} @ 20: 40: 40 \mathrm{Kg} / \mathrm{ha}$ in the form of urea, single super phosphate and murate of potash respectively, was giving to plots prior to sowing.

\section{Seed treatment and sowing of seeds}

Inoculation of seed with Rhizobium considerably influenced on growth parameters and soil fertility by alternating $\mathrm{N}$-content. The groundnut seed var. Devi was inoculated with Rhizobium culture before sowing @ 200g per 10-12 Kg kernel and was sown in lines after treatment with Rhizobium culture.The lines were drawn $25 \mathrm{~cm}$ apart by trench hoe and seeds were sown in furrows at equal depth maintaining a spacing of $10 \mathrm{~cm}$.

\section{Herbicide application}

After 2 days of sowing, proper dose of preemergence herbicide mixed well with required quantity of water and allow it to stand for 5-10 minutes. Then it was sprayed with the help with the help of a high volume knapsack sprayer. The spraying of herbicide was given as uniform blanket spray over the soil. All the spraying operations were done during evening hours.

\section{Methods of data collection}

\section{Number of pods per plant and effective pods per plant}

Five plants which were selected at random from each experimental plot were uprooted carefully and number of pods and effective pods were counted individually.

\section{Weight of pods per plant}

The pods obtained from the sample plants were separated and were washed, dried in the sun for 3 days and then dry their dry weights were recorded. The weight of pods per plant was obtained by dividing the number of plants i.e. 5 with the total weight of pods.

\section{Kernel weight per plant}

The pods from the sample plants were decorticated and the kernel weighted $(\mathrm{g})$ per plant obtained by dividing with the numbers of plants.

\section{0 kernels weight (Test seed weight)}

100 kernels were chosen from the sample plants at random and were weighed $(\mathrm{g})$ after 
three consecutive sun drying for 4 hours a day under paper cover.

\section{Shelling percentage $(\%)$}

The oven dried pod sub-samples taken from the entire harvest of each experimental plot were weighed (pod dry weight) and then hand shelled. The shelled grain and the husks were weighed separately and the shelling percentage was calculated using the formula;

Shelling percentage $=($ weight of seeds/weight of unshelled pods) $\mathrm{x} 100$

\section{Pod yield}

One row on both sides of the length and $20 \mathrm{~cm}$ border from breath side of the gross plot were removed to eliminate the boarder effect. The pod yield from individual net plots was recorded in $\mathrm{kg}$ after 3 consecutive sun drying from this observation the yield per hectare was computed in quintal per hectare.

\section{Harvest index}

Harvest index (\%) was calculated by using the formula

Harvest index $(\%)=($ Seed Yield per plant $/$ Total Dry Weight per Plant) x100h. Oil Estimation

Two grams of Groundnut seeds from each treatment were crushed in a glass mortar and placed in a thimble. The thimble containing crushed seeds was placed in a Soxlet extraction apparatus connected with a preweighed extraction (receiving) Flask containing $150 \mathrm{ml}$ of petroleum ether. Extraction flask was heated on water bath for about 3 to $4 \mathrm{hrs}$. The solvent (Petroleum ether) was circulated through the condenser of Soxlet apparatus continuously over the entire refluxing period. Receiving flask was detached and placed in an oven at $60-80^{\circ} \mathrm{C}$ for complete removal of petroleum ether, the receiving flask containing oil was calculated as follows (Singh, 1997)

Percentage Oil $=\mathrm{W}_{0} / \mathrm{Ws}$

$\mathrm{W}_{0}=$ Weight of oil in gram (final weight of receiving flask with oil-initial weight of receiving flask)

$\mathrm{W}_{\mathrm{s}}=$ Weight of seeds taken in gram

\section{Harvest of oil}

Harvested oil was computed from percent of oil present in kernel and pod yield and express as $\mathrm{q} / \mathrm{ha}$

\section{Data analysis}

The experimental design adopted for this research work was simple Randomized Block Design (RBD). The obtained data were statically analyzed following the RBD as out lined by Panse and Sukhatme (1985).

\section{Results and Discussion}

\section{Total number of pods per plant}

The total number of pods per plant was recorded at different growth stage has been represented in figure 1. It was found that the total number of pods per plant recorded at 45DAS was found to be maximum (20.03 pods/plant) in $\mathrm{T}_{4}$ (weed free check) plot followed by $\mathrm{T}_{1}$ (Butachlor) (18.73 pods/plant), and oxyflurofen (18.53 pods/plant) whereas minimum value of the same was shown in weedy check control (15.37 pods/plant). The percentage of increase over the weedy check control at $30 \mathrm{DAS}$ in $\mathrm{T}_{4}$ was $(30.31 \%)$ followed by $\mathrm{T}_{1}$ (Butachlor) $(21.86 \%)$. Similar trend was observed at 60 DAS and 90 DAS. At 90 DAS the 
$\mathrm{T}_{4}$ contributed maximum number of pods per plant, which was $33.46 \%$ increased over the weedy check control. Significant difference among the treatments was noted as regards to total number of pods per plant.

\section{Number of pods per plant, at harvest}

From figure 1, it was revealed that the total number of pods/plant at harvest was maximum (33.33) in weed free plot followed by Butachlor treated plot (31.47) whereas the minimum value of the same was recorded from control (27.30).

The percentage of increase of total number of pods per plant was maximum (22.09) over the weedy check control.

\section{Number of effective pods/plant}

Data presented in figure 2 showed that, the number of effective pods per plant, due to the application of pre-emergence of herbicides, increased over the control irrespective of growth stage and treatments. Data recorded at 45, 60, 90 DAS and at harvest stage indicated that $\mathrm{T}_{4}$ (Weed free check) contributed highest number of effective pods i.e.10.05, 18.00, 19.86 and 23.70 respectively, which were $24.5 \%, 53.85 \%, 38.86 \%$ and $21.33 \%$ increase over the control in the respective growth stages. The $\mathrm{T}_{1}$ (Butachlor) and $\mathrm{T}_{3}$ (Oxyflurofen) treated plots contributed second and third highest number of effective pods per plant in the growth stages.

\section{Pod weight per Plant}

Variation in number of pod weight (g/plant) due to the effect of pre-emergence application of herbicides at harvesting stage was presented in table 1. From the table it was noticed that highest pod weight $(27.80 \mathrm{gm} / \mathrm{plant})$ was contributed by weed free plot followed by Butachlor treated plots (26.14 gm/plant). The percentage of increased in pod weight over the control was as in the following sequence

Weed freecheck $\left(\mathrm{T}_{4}\right) 65.47 \%>$ Butachlor $\left(\mathrm{T}_{1}\right)$ $55.59 \%>$ Oxyflurofen $\left(\mathrm{T}_{3}\right) 31.49 \%>$ Alachlor $\left(\mathrm{T}_{1}\right) 22.92 \%>$ Weedy check Control $\left(\mathrm{T}_{0}\right)$

\section{Test weight (100 kernel weight)}

Data presented in table 1 indicated that maximum 100 kernel weight was exhibited by weed free plot $(59.84 \mathrm{gm})$ followed by Butachlor (54.59 gm) and Oxyflurofen (51.83 $\mathrm{gm})$. The percentage of increased over the control was 30.13, 8.42, 23.55 and 42.67 in butachlor treated plots, alachlor treated plots, Oxyflurofen treated plots and weed free plots respectively.

\section{Kernel weight/plant}

From the table 1, it was revealed that weed free plots, contributed highest kernel weight per plant $(23.30 \mathrm{gm} /$ plant $)$ followed by Butachlor treated plots (21.24 gm/plant), which were $93.36 \%$ and $76.26 \%$ increased over the control.

\section{Yield/ha}

Due to the application of pre-emergence herbicide in Groundnut crop, there was variation in yield among the treatments. Data presented in table 1 indicated that the highest yield was obtained in weed free check (13.92 $\mathrm{q} / \mathrm{ha}$ ) followed by Butachlor treated plots (13.17 q/ha) which were $26.55 \%$ and $19.73 \%$ increase over the weedy check control.

\section{Shelling percentage}

The effect of pre-emergence herbicides has tremendous effect on shelling percentage of Groundnut. From the data presented in table 1 revealed that highest shelling percentage was exhibited in weed free check $(83.81 \%)$ 
followed by Butachlor treated plot $(81.28 \%)$, whereas the weedy check control plot contributed the lowest value (71.95\%).

\section{Harvest index}

Variation in harvest Index due to the effect of pre-emergence herbicide was observed and reflected in table 1. It was found that highest
Harvest Index (59.59 \%) was observed in weed free check $\left(\mathrm{T}_{4}\right)$ followed by Butachlor treated plots $\left(\mathrm{T}_{1}\right)$ was $(58.66 \%)$ whereas the lowest value of the same was observed from the control plot $(52.36 \%)$. The $\mathrm{CV}$ value presented in table 1 indicated that there was no wide variation among the treatments. Significant difference was noted among the treatments.

Table.1 Effect of pre emergence herbicides on yield and yield attributing character of groundnut

\begin{tabular}{|l|l|l|l|l|l|l|l|}
\hline \multicolumn{2}{|c|}{ Treatments } & $\begin{array}{l}\text { Pod Weight } \\
\text { (Gram/Plant) }\end{array}$ & $\begin{array}{l}\text { 100 Kernel } \\
\text { Weight } \\
\text { (g) }\end{array}$ & $\begin{array}{l}\text { Kernel } \\
\text { Weight } \\
\text { (g/Plant) }\end{array}$ & $\begin{array}{l}\text { Pod Yield } \\
\text { (Q/Ha) }\end{array}$ & $\begin{array}{l}\text { Shelling } \\
\text { Percentage }\end{array}$ & $\begin{array}{l}\text { Harvest } \\
\text { Index(H.I.) }\end{array}$ \\
\hline $\mathrm{T}_{0}$ & $\begin{array}{l}\text { Weedy check } \\
\text { Control }\end{array}$ & 16.89 & 41.95 & 12.15 & 11.58 & 71.95 & 52.36 \\
\hline $\mathrm{T}_{1}$ & Butachlor & 26.14 & 54.59 & 21.24 & 13.17 & 81.28 & 58.66 \\
\hline $\mathrm{T}_{2}$ & Alachlor & 20.65 & 45.48 & 15.29 & 11.00 & 74.02 & 55.18 \\
\hline $\mathrm{T}_{3}$ & Oxyflurofen & 22.09 & 51.83 & 16.79 & 11.75 & 76.01 & 56.61 \\
\hline $\mathrm{T}_{4}$ & $\begin{array}{l}\text { Weed } \\
\text { freecheck }\end{array}$ & 27.80 & 59.85 & 23.30 & 13.92 & 83.81 & 59.59 \\
\hline & CD 5\% & 0.38 & 2.38 & 0.64 & 0.68 & 1.86 & 0.54 \\
\hline
\end{tabular}

Fig.1.Effect of pre-emergence herbicides on the total number of pods per plant of groundnut var. Devi

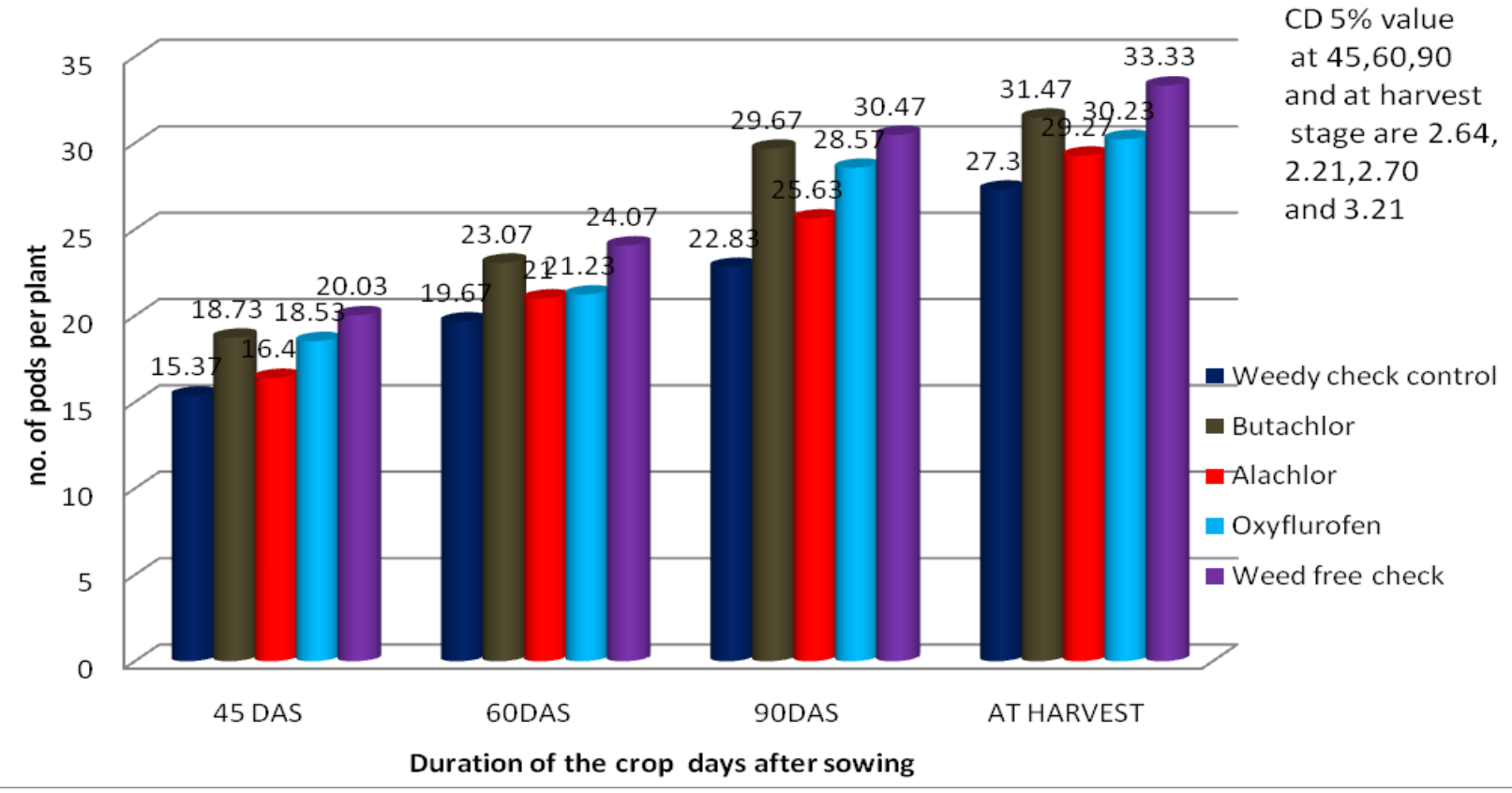


Fig.2.Effect of pre-emergence herbicideson numberofeffective pods per plant of groundnut var. Devi

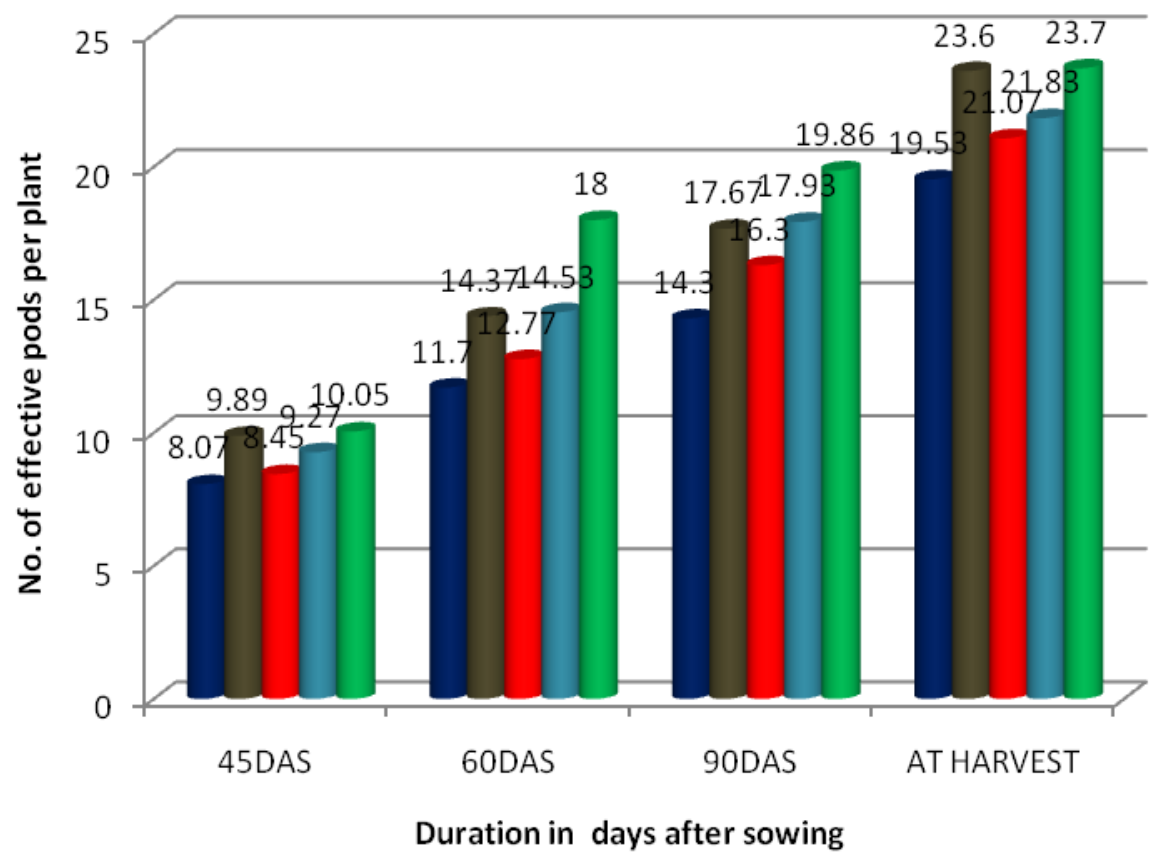

CD $5 \%$ at $45,60,90$ DAS and at harvest are1.203 $1.412,1.841$ and 2.326

- Weedy check control - Butachlor

- Alachlor

Oxyflurofen

Weed free check

Fig.3.Harvest Oil (q/ha) content due to the effect of Pre emergence Herbicides

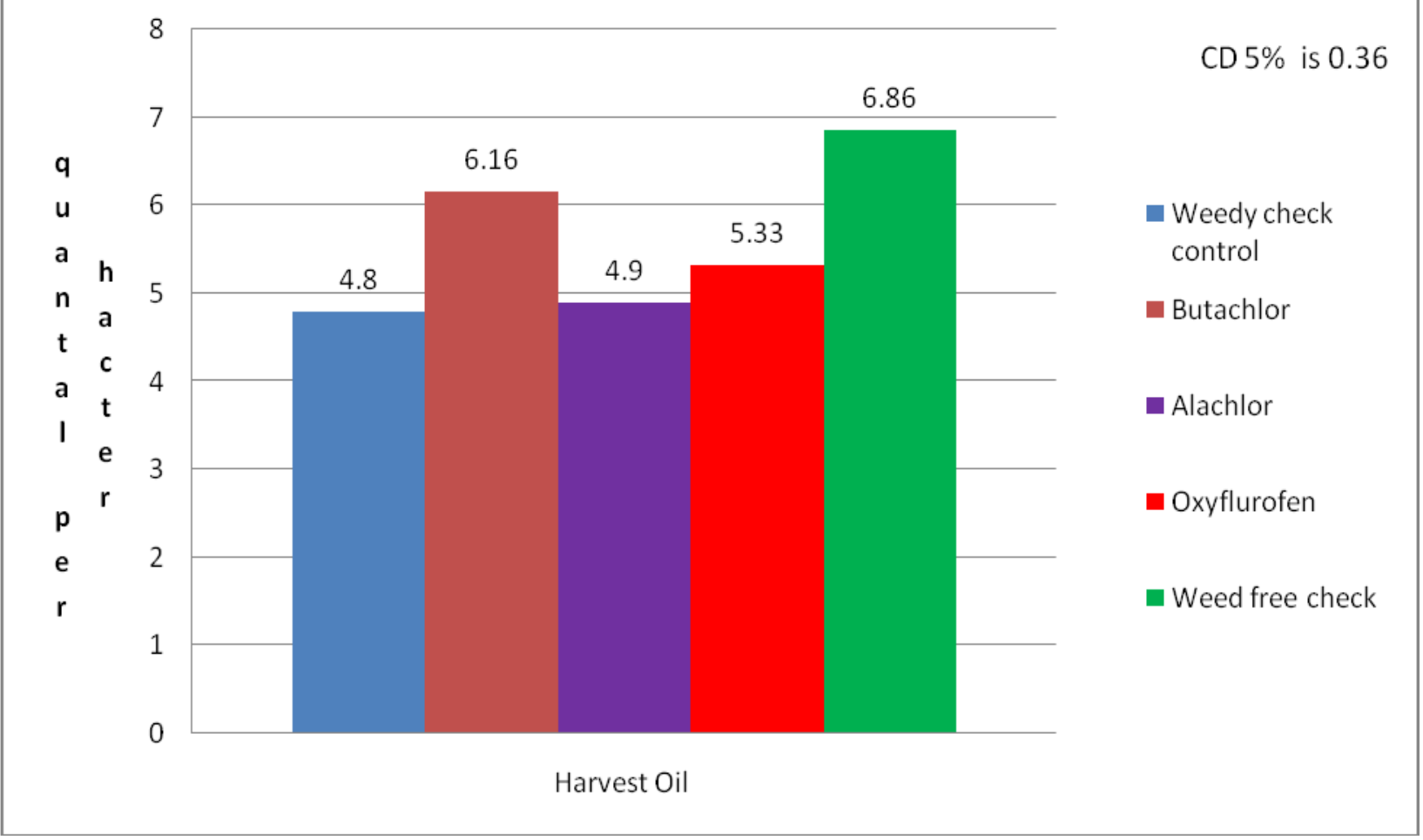




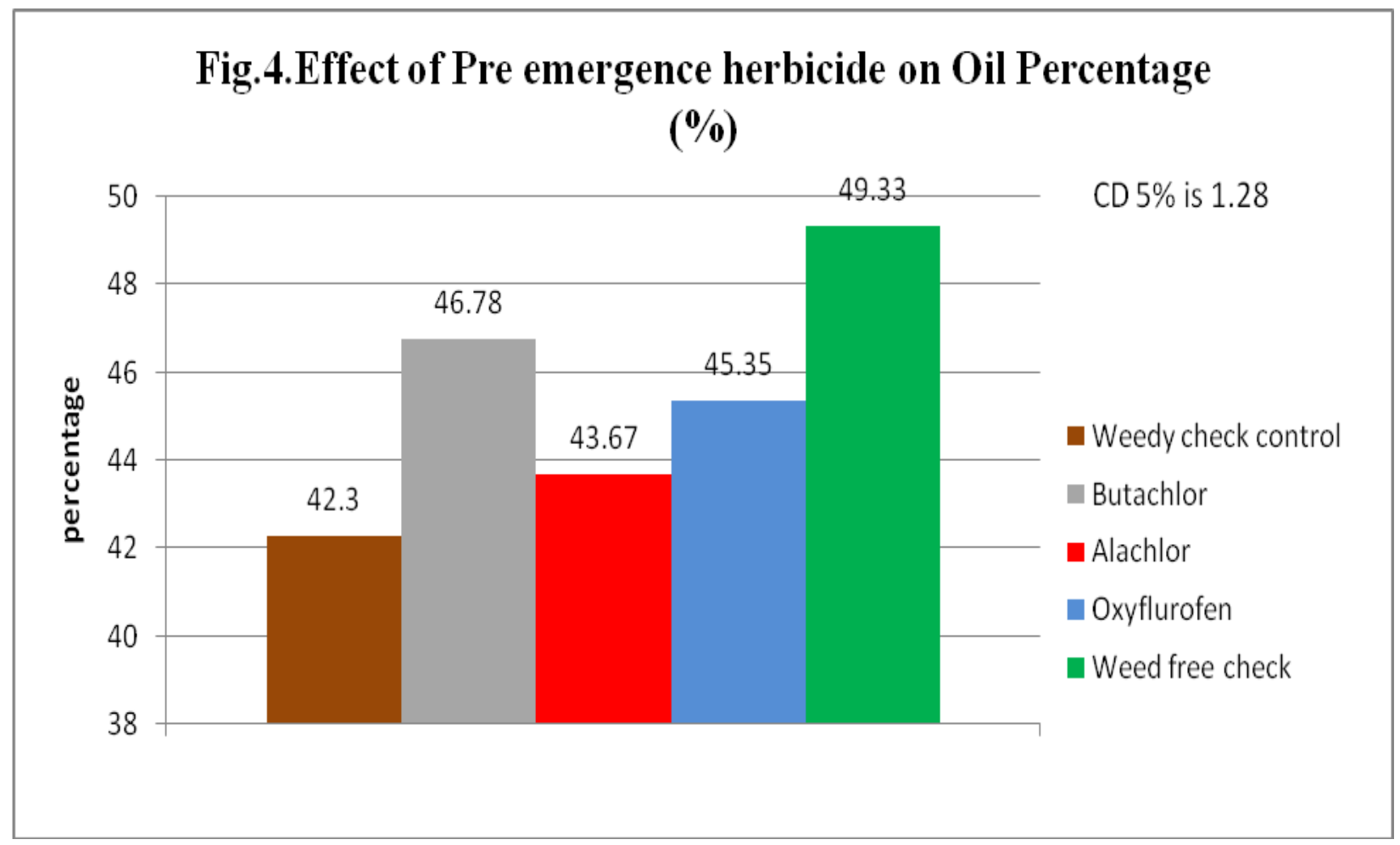

\section{Harvest oil (q/ha) and oil percentage}

Due to the application of pre-emergence herbicides, there was variation in harvesting oil. Data presented in figure 3. Indicated that the maximum harvest oil $(6.86 \mathrm{q} / \mathrm{ha})$ was contributed by weed free check $\left(T_{4}\right)$ followed by Butachlor treatment $(6.16 \mathrm{q} / \mathrm{ha})$ whereas the minimum value $(4.80 \mathrm{q} / \mathrm{ha})$ was recorded in weedy check control.

Data presented in figure 4. Indicated that due to the application of pre-emergence herbicide, there was significant increase in oil percentage among the treatments and the maximum oil percentage was exhibited by weed free check (49.33\%), whereas the minimum value of the same was recorded in weedy check control (42.30\%). The percentage of increased in oil percentage over the control followed the following sequence

Weed free $(16.62 \%)>$ Butachlor $(10.59 \%)>$ Oxyflurofen (7.21\%) >Alachlor (3.24\%) $>$ Control
Effect of phyto toxic properties of preemergence herbicides on yield and yield attributes of groundnut

From the data, it was noticed that weedy check control recorded significantly lower pod yield (11q.ha-1) over rest of the treatments. This may be due to greater weed competition resulted in significantly higher uptake of nitrogen, phosphorous and potassium by weeds in weedy check as compared to other treatments. These findings is in conformity with the results obtained by Rajendran and Louduraj (1999) and Devi Dayal and Ghosh (1999) viewed that in groundnut, the loss in pod yield ranges from 13 to $100 \%$ depending on the season, cultivars, weed composition and duration of crop weed competition, and the packages of practices adopted.

Nambi and Sundari (2008) conducted an experiment on weed flora of Groundnut to study the phyto physiology and found that highest pod yield was realized under 
completely weed free condition. Maintaining weed free environment resulted in maximum yields in groundnut as reported by Paulo, Kasai and Carichioli (2001). Our experiment signifies the findings of previous workers by producing high pod yield (13.92q ha-1) in weed free condition.

In this experiment along with these two treatments i.e. weedy check control $\left(\mathrm{T}_{0}\right)$ and weed free treatment $\left(\mathrm{T}_{4}\right)$ we had also taken three treatments of pre emergence herbicides i.e. butachlor $\left(\mathrm{T}_{1}\right)$, oxyflurofen $\left(\mathrm{T}_{3}\right)$ and alachlor $\left(\mathrm{T}_{2}\right)$ with 2 manual weeding. The study revealed that among these three treatments butachlor treatment results high yield $(13.17 \mathrm{q} / \mathrm{ha})$ followed by oxyflurofen treatment $(11.75 \mathrm{q} / \mathrm{ha})$ as compare to alachlor treatment $(11.58 \mathrm{q} / \mathrm{ha})$.So this finding indicates that Herbicide application to groundnut had the significant influence to increase the groundnut yield. Results indicated that all the herbicidal treatments as well as weed free check resulted in significant increase in yield and yield attributing characters of groundnut along with reduction in the weed population and weed biomass production, compared to weedy check control. This finding corroborates the findings of Gunri et al., (2014). The enhancement in the seed yield due to various weed control measures was because of the fact that they helped to keep the field comparatively free from weeds, thus resulting in better utilization of resources namely, nutrients, moisture, solar light etc. This consequently led to the production of more vigorous and healthy plants having more pod bearing capacity, more seed per pod and 100-seed weight. The cumulative effect of all these resulted in higher seed yields, this results confirm the findings of Pandya et al., (2005) and many others who reported enhanced soybean yield due to various weed control treatments. Weedy check produced lowest yield of soybean which was significantly inferior to different weed control treatments. All herbicidal treatments significantly increased yield and yield components like seed yield, test weight, pod dry weight, number of pods per plant, number of seeds per plant, harvest index as compare to weedy check control.

There is a peculiarity in the reproduction of Peanut seed. Flowers are produce above ground and upon fertilization, structures called gynophores (pegs) are produced that grow downward until they contact and penetrate the soil. The peanut is formed as a swelling of the tip of the peg. The first flowers are produced near the center mass of the plant and continue out on the plant stems as the plant grows. The reproductive structure is somewhat vulnerable to chemical damage. Conventional herbicide is generally applied prior to planting and emergence of seed to control weeds until the canopy is able to over growth the inter-row spaces and shade out germinated weeds by competition. By this process there is little chance that the pegs will be damaged by application of herbicides during the development may cause the pegs to be damaged (Russo et al., 2012). The damaged in pegs affects the photosynthesis by blocking the electron transport chain in PS -II and diversion of electron transport through PS-I thus there was reduction photosynthesis processes as a result of which photosynthates are produced in less. So translocation of photosynthates is reduced. This may be the reason due to which weed free treatment shows better performance in yield and attributing characters than herbicide treatments (Zaidi et al., 2005; Gunri et al., 2014).

Khan et al., (2004) conducted an experiment and found different levels of phyto-toxic effects of various herbicides on legumes. In our experiment we had taken butachlor, alachlor and oxyflurofen. Among these herbicides butachlor have tendency to high 
weed control efficiency and responsible for greater translocation of photosynthates resulting in increase in fruit weight of plant (Singh et al., 2011). Oxyflurofen shows its phytotoxic effect by disrupting cell membrane with inhibiting an enzyme which manufactures chlorophyll. Consequently, accumulation of a prechlorophyll molecule occurs that is capable of accepting light energy, but cannot pass it along to the photosynthesis process. As a result, energy builds up in the leaf until cell membranes are destroyed. Alachlor composed of chloroacetamide and it absorbed into the shoots of emerging plants and toxicity results into deformation or curling ( $\mathrm{J}$ rooting) of groundnut root.

Our findings revealed that butachlor treatment have less phytotoxic effect due to its greater translocation ability but among oxyflurofen and alachlor treatment, alachlor treatment dominated over oxyflurofen due to higher phytotoxic effect by deforming the root structure.

Effect of phyto toxic properties of preemergence herbicides on oil content of groundnut

The harvested oil and oil content percentage was found maximum in weed free plots $(6.86$ $\mathrm{q} /$ ha $\& 49.33 \%$ ) followed by butachlor treated plots $(46.78 \%)$ increased over the control (42.30\%).Due to lesser weed population the nutrient uptake was more in the other treatments compared to control.

So the kernel weight was higher in a result of which the harvested oil and percentage was more. Enhancement of oil content of groundnut as affected by various herbicidal treatments measures may be attributed to better nutrition of the groundnut which plays a vital role in improving value of groundnut. All most similar finding was observed in case of soybean by EL-Metwally and Shalby (2007).

Our findings suggested that manual weeding i.e. hand weeding produce the highest groundnut yield. If it is not possible due to larger field size or labour scarcity then application of butachlor with two hand weeding at 21 and 40 DAS would be suitable option for better yield and oil content followed by oxyflurofen treatment with two hand weeding at 21 and 40 DAS as compare to alachlor treatment with two hand weeding at 21 and 40 DAS. Further studies are needed to determine the most suitable herbicide with respect to physiological and molecular study.

\section{References}

Anderson and Domsch. 1989. Herbicidal effect on crown rhizobia and nodule activity, Weed Science, 34. 338-343.

Devi Dayal and Ghosh, P. K.1999. Recent advances in weed management for groundnut in India. Abs. Biennial Conference on weed control, B. H. U., Vanarasi, 5-7.

El-Metwally, I.M., Shalby E.M. 2007. BioRemediation of fluazifop-p-butyl herbicide contaminated soil with special reference to efficacy of some weed control treatments in faba bean plants. Res. J. Agric. Bio. Sci. 3(3): 157-165.

Gill, S.S., Tuteja, N.2010. Reactive oxygen species and antioxidantmachinery in abiotic stress tolerance in crop plants. - Plant Physiol. Bioch.48: 909-930.

Gunri, S.K., Sengupta A, Nath R, Bera P.S. and Puste A.M. 2014, evaluation of post emergence of herbicides on summer groundnut(Arachis hypogaea) in alluvial soils of west Bengal, African Journal of Agricultural Research, 9(40): 2971-2974.

Heinonen-Tanski, H., Oros, G.,Kecskes, M. 1982.The effect on soil pesticides on the growth of red clover rhizobia. Acta Agric Scand 32: 283-288.

Jaiswal, V. P. 1994.Different response of weed species to herbicides in potato. J. Indian 
Potato Assoc. 21: 157-159.

Jhala, A., P.H. Rathod, K.C. Patel, Van Damme P.2005.Growth andb yield of groundnut (Arachis hypogeae L.) as influenced by weed management practices and Rhizobium inoculation, Commun Agric Appl Biol Sci,70 (3):493-500.

Kabir, R., S. Yeasmin, A.K.M Islam, Sarkar M. A.R. 2013. Effect of Phosphorus, Calcium and Boron on the Growth and Yield of Groundnut (Arachis hypogea L.). International Journal of Bio-Science and Bio-Technology, 5(3):51-59.

Khan, M.S., Zaidi A., Aamil M. 2004. Influence of herbicides on chickpea Mesorhizobium symbiosis, Agronomie 24, 123-127.

Mallik, M.A.B., Tesfai, K. 1985. Pesticidal effect on soybean rhizobia symbiosis. Plant Soil 85:33-41.

Nambi, J., and Sundari, A. 2008.Phytosociological studies of weed flora of groundnut (Arachis hypogaea L.) fields in Cuddalore district of Tamilnadu. In: National symposium on IAPEA, pp. 122-124.

Pandya, N., Chouhan GS, Nepalia V. 2005. Effect of varieties, crop geometries and weed management on nutrient up take by soybean (Glycine max) and associated weeds. Indian J. Agron.50 (3):218-220.

Paulo, E.M., Kasai, F.S., and Carichioli, J.C.2001. Effect of weed competition periods on peanut II. Wet season crop. Bragantia. 60:27-33.

Rajendran, K., and Lourduraj, A.C. 1999. Weed management in groundnut a review. Agricultural Review, 20: 59-62.

Rennie, R.J., Dubetz, S. 1984. Effect of fungicides and herbicides on the nodulation and N2 fixation in soybean fields lacking indigenous Rhizobium japonicum. Agron J 76:451-454.

Russo, V.M., Webber C.L., 2012. Peanut pod, seed, and oil yield for biofuel following conventional and organic production systems. Industrial Crops and Products 39: $113-119$.

Savage, G.P., Keenan J.I., 1994.The composition and nutritive value of groundnut kernels.I Smart J. (ed). The Groundnut Crop: Scientific basis for improvement, London: Chapman and Hall, pp. 173-213.

Settaluri, V. S., C. V. K. Kandala, N. Puppala, Sundaram J. 2012.Peanuts and Their Nutritional Aspects-A Review.Food and Nutrition Sciences, 3.1644-1650.

Singh, U., Hiremath S. M, Halikatti S. I., Shashidhara G. B., and Patil P. L. 2011. Evaluation of herbicides for weed control in rainfed transplanted chilli (Capsicum annuum L.) Karnataka J. Agric. Sci., 24 (2): 125-128.

Taphee, G.B., Jongur A.A.U. 2014. Productivity and Efficiency of Groundnut Farming in North Taraba state. Journal of Agriculture and Sustainability, 5(1):45-56.

USDA-ARS., 2008.Peanut biodiesel from the field to the fuel tank. South Atlantic National Peanut Research Lab, USA.

Wright, D.L., 2012. Production of biofuel crops in Florida: peanut. SS AGR 295. Agronomy Department, Florida Cooperative Extension Service, Institute of Food and Agricultural Sciences, University of Florida.

Zaidi, A., Khan S, Rizvi P.Q. 2005. Effect of herbicides on growth, nodulation and nitrogen content of greengram, Agronomy. Sustainable. Development. 25: 497-504.

\section{How to cite this article:}

Soumya Kumar Sahoo, Jyostnarani Pradhan, V.B. Kuruwanshi, Arti Guhey, G.R. Rout and Rabiratna Dash. 2017. Phytotoxic Effect of Pre emergence Herbicides on Oil Content and Yield Components of Groundnut (Arachis hypogeae). Int.J.Curr.Microbiol.App.Sci. 6(9): 1738-1748. doi: https://doi.org/10.20546/ijcmas.2017.609.215 